\title{
TRAGIC COLLAPSE OF A MUSICIAN WITH SYPHILIS IN DOCTOR FAUSTUS
}

\section{Prof. Dr. Nurullah ULUTAŞ*}

\begin{abstract}
In world literature, "Faust" or "Faustus" is the hero of an ancient and popular medieval German classical myth. This concept, which is thought to be derived from German epics, inspires many artists. Apart from the works created with this name on its own, it corresponds with various references in many works. He made a deal with the devil due to his curiosity and was eventually cursed. Although the historical origin of the name and character of Doctor Faustus is not very clear, many sources report that he was a German doctor named Johann Georg Faust. He was also a sorcerer and alchemist who probably lived around Wittenberg in Germany in the first half of the 1500s. Many references have been made to this concept in many works along with the works titled with this name. Although many works have been written on Faust, especially the works of Marlove and Goethe remain a masterpiece.

One of them is Thomas Mann's novel Doctor Faustus which was first published in German in 1947. In this novel, the biography of Adrian Leverkühn, an extremely talented and intelligent person, is handled with a subjective approach. A composer who was first interested in the field of religious sciences, suddenly changed his direction to the field of music. When he was at the top of his profession, he slept with a prostitute, contracted syphilis, and died as a result of a tragic collapse.

In this work of Thomas Mann, which is described as a masterpiece by some critics, the author manifests his intellectual identity as in his other novels. The artist, floundering in the conflict of mind and emotion, makes a deal with the devil who comes to visit him one night when he is in spiritual bondage. According to this agreement, on the condition that he renounces love and affection for 24 years, the devil will inspire him with great compositions and he will reach the top of his profession. The author habitually touches upon almost every discipline, especially art and medicine. While the reader goes back and forth through the plots of the novel, he also develops his general culture. The author does not neglect to inform the reader in this context. In this novel, details about the science of music bring additional value to the novel. The author also criticizes Germany's Nazi authority through an artist who suffers from syphilis. He uses political criticism by associating syphilis with the political, economic, and democratic collapse of the authority. In addition to syphilis, typhus and pneumonia are also mentioned in the novel.
\end{abstract}

*Bitlis Eren Üniversitesi İslami İlimler Fakültesi. 
This study analyses the psychological collapse and the loss of social dignity of a musician through Thomas Mann's novel titled Doctor Faustus.

Key Words: Thomas Mann, Doctor Faustus, German literature, music, syphilis.

\section{DOKTOR FAUSTUS ROMANINDA FRENGIYE YAKALANAN} BİR MÜZISYENIN TRAJIK ÇÖKÜŞÜ

Öz: Dünya edebiyatında "Faust" veya "Faustus" kavramları çok yaygındır. Alman destanlarından türediği düşünülen bu kavram, birçok sanatçıya ilham verir. Başlı başına bu adla oluşturulan yapıtlar dışında birçok yapıtta çeşitli göndermelerle karşılık bulur. Faust ya da Faustus oldukça eski ve popüler bir orta çağ Alman klasik söylencesinin kahramanıdır. Büyüye olan merakı yüzünden şeytanla anlaşma yapıp sonunda lanetlenmiştir. Tarihsel olarak Doktor Faustus adının ve karakterinin kaynağı çok belirgin olmamakla beraber, birçok kaynakta muhtemelen 1500'lü yılların ilk yarısında Almanya' da Wittenberg civarında yaşamış bir büyücü ve simyager olan Alman Doktor Johann Georg Faust olduğu görüşü yaygın olarak kabul görür. Faust üzerine birçok eser yazılsa da özellikle Marlove ve Goethe'nin yapıtları bir şaheser olma niteliğini korumaktadır.

Thomas Mann'ın Almanca ilk baskısı 1947 yılında yapılan Doktor Faustus adlı romanı da bu yapitlardan biridir. Bu romanda, son derece yetenekli ve zeki biri olan Adrian Leverkühn'ün biyografisi öznel yaklaşımlarla ele alınır. Bu yapıtta önce din bilimleri (İlahiyat) alanına yönelen sonra bir anda yön değiştirip müzik alanında karar kılan bir bestekârın hayatı anlatılır. Akıl duygu çatışması içerisinde bocalayan sanatçı, ruhsal esaret yaşadığı bir gece kendisini ziyarete gelen şeytanla bir anlaşma yapar. Bu anlaşmaya göre, 24 yıl boyunca aşk ve sevgiden vazgeçmesi şartıyla şeytan ona büyük besteler ilham edecek ve o da mesleğinin zirvesine erişecektir. Ancak bir hayat kadınıyla birlikte olup frengiye yakalanan Adrian Leverkühn, bu hatasının bedelini trajik bir çöküş sonucu ölümle öder.

Thomas Mann, bazı eleştirmenler tarafından bir başyapıt olarak nitelenen Doktor Faustus adlı eserinde diğer romanlarında da görüldüğü üzere entelektüel kimliğini hissettirir. O, romanlarında sanat ve tıp başta olmak üzere hemen tüm disiplinlere yönelmeyi alışkanlık edinir. Okuyucu romanın olay örgüleri içinde gidip gelirken genel kültürünü de geliştirir. Yazar, bu bağlamda okuyucusunu bilgilendirmeyi ihmal etmez. Bu romanda da teknik olarak başkalarından faydalansa da müzik bilimiyle ilgili ayrıntılar, romana bir değer katar. Frengi hastalığının yarattığı kötü sonuçlar bir sanatçı üzerinden işlenir. Bu hastalığın şeytanla yaptığı anlaşma sonucunda büyük besteler yapan Adrian Leverkühn'ü nasıl adım adım yıprattığı ve trajik bir ölüme sürüklediği romanda işlenir. Yazar, frengi hastalığını aynı zamanda Almanya'nın Nazi yönetimi yüzünden siyasal, ekonomik ve demokratik anlamda çürümeye yüz tutmasıyla da ilişkilendirir. Romanda frengi dışında tifüs ve zatürre hastalıklarına da değinilir.

Bu çalışmada Thomas Mann'ın Doktor Faustus adlı yapıtı üzerinden bir müzisyenin psikolojik çöküşü ve toplumsal itibarını nasıl kaybettiği analiz edilecektir.

Anahtar Kelimeler: Thomas Mann, Doktor Faustus, Alman edebiyatı, müzik, frengi.

\section{Introduction}

The concepts of "Faust" or "Faustus" considered to derive from German epics also inspire many artists of world literature. This concept, which initially found its place in epics, is used in works following the transition to the modern novel and theater. It corresponds to various references in many works in addition to the those created solely with this name: "Faust or Faustus is the protagonist of a rather ancient and popular medieval German classic prose: Because of his curiosity for magic, he makes a deal with the devil and is finally cursed. 
While the source of the name and character of Doctor Faustus is not historically very clear, it is widely accepted in many sources that he is probably the German Doctor Johann Georg Faust, a sorcerer, and alchemist who lived around Wittenberg in Germany in the first half of the 1500s." (Solid, 2010: 8).

Although many works have been written on "Faust", the works of Marlowe and Goethe in particular, maintain the quality of a masterpiece: "Among the artists who have been posing such questions through works of art since the existence of man, the English playwright and poet Christopher Marlowe (1564-1593) and the German author and poet Goethe (1749-1832) have a privileged place. Their works play a major role in the transmission of the character, Faust, who tried to overcome the limitedness of the human mind through an agreement with the devil to be able to solve the secrets of the universe and sold his soul to the devil in exchange for more information, and in Faust's transformation to a symbol of the contradictions of modern man." (Solid, 2010: 8). Dr. F. character, who takes place in the stage play The Hidden Bazaar by Turgay Nar, corresponds to Faust in Turkish literature. (Ulutaş, 2016: 673).

Thomas Mann's 1947 novel Doctor Faustus with the first edition dating back to 1947, is one of these works. In this novel, the biography of Adrian Leverkühn, a highly skilled and intelligent person, is assessed with subjective approaches. The work narrates the life of a composer who first heads for the field of religious sciences, and then suddenly changes his direction and decides to pursue the field of music. Faltering in the conflict of mind and emotion, the artist makes a deal with the devil that comes to visit him on a night of spiritual captivity. Under this agreement, the devil will inspire his great compositions, provided that he gives up love and affection for 24 years, and he will reach the pinnacle of his profession: "Man's agreement with the devil; selling his soul to the devil in exchange for youth, knowledge, wealth or power, or in a more general way, collaborating with evil forces for his satisfaction to fulfill one's wishes, is the main theme of Faust stories. And now the word Faust becomes adjective Faustesque (selling one's soul to the devil)." (Sağlam, 2010: 8).

The artist, who soon created great compositions with his inspirations from the devil, meets and passionately gets connected to a prostitute, whom he named Esmeralda when he lives in Leipzig at the beginning of the novel:

"That's what it would mean if Adrian went there, to that house, for a certain person; The girl she called 'Esmeralda', a brunette with a tiny jacket and a big mouth who roasted his cheek with a touch of her arm approaching when she was near the piano. There, he looked for her in that house, he called her, but he couldn't find her." (Mann, 2014: 223).

Looking everywhere for this woman, Adrian finally found her. The woman immediately understood that this young man comes home for her, and says, 
after thanking him, that they should not be together. Despite the woman's insistence, Adrian fell for his sexual desire and made love to her: "The poor spirit of this prostitute seemed capable of responding to the feelings the young man manifest. Of course, he recognized the guest who had stopped by briefly once. (...) She learned from him that he risked taking this trip only for her, thanked him, and warned him to stay away from her body. (...) Dear God, what kind of love or whatsoever, what kind of addiction, and what kind of a desire would cause the man to dare to oppose God. (...) What a mysterious desire it was that the person would insist to have the woman's skin without caring about the warning that he would leave his body of demonic evil, and would bring about a lethal chemical change to his nature." (Mann, 2014: 225).

Adrian Leverkühn, who becomes sick after this intercourse, is diagnosed with syphilis (gonorrhea): "The doctor kept puffing during the physical examination cause he immediately got to work saying that a comprehensive and very long-term treatment process was needed with his statements in complete contradiction with his puffs. For the next three days, Adrian went to the doctor to continue the treatment." (Mann, 2014: 227).

The fact that the author makes his novel character face such a disease as soon as he advances to the top of his career is that's the breaks. An artist on his way to becoming a genius begins to roll into a tragic end because of his desires that he cannot control: “ (...) his soul is filled with desire and will to create. This emotional tension, of which Leverkühn is convicted, is a constant obstacle to his soul's release from his obsessions. That's where the deal with the devil is done: Holding Adrian Leverkühn's hand, the devil grants him the power to create brilliant artifacts, while at the same time dragging him towards a terrible end: A venereal disease removes Leverkühn's obstacles to become a prodigy and genius; syphilis allows him to survive an existence doomed to remain meaningless without the manifestation of the creative mind. But this is a genius and creativity that only evil can provide, and it represents the intoxication of people with fascism in Thomas Mann aesthetics." (https://www.haber7.com/kitap/haber/1110392-doktor-faustus-ilk-kez-turkcede/(Date Accessed: 08/10/2020).

Syphilis (gonorrhea) is often one of the sexually transmitted epidemics that threaten humanity throughout history. This disease, which is caught from someone carrying this disease and of which the source is the indication of an extramarital affair that threatens marriages:

"Among the nineteenth-century diseases, syphilis, which spread terror with the name, was not considered at least an enigmatic disease. Contracting syphilis was a predictable and often common consequence of having sexual inter- 
course with someone who had the same disease. So, among guilt-recalling fantasies on sexual evil linked to syphilis, there was no room for a default personality type in which man was particularly prone to this disease (as formerly thought for tuberculosis, now cancer). The personality type with syphilis is not likely to be syphilis; rather he was just someone who had that disease." (Sontag, 2005: 44)

Many diseases, especially syphilis and AIDS, are the troubles that make a modern man lose his sleep and make him a prisoner of fear. In a world that progresses in the field of science, industry, and technology with modernism, where communication develops very quickly and people have very easy access to everything they desire, a culture of fear created by this independence has reached an uncomfortable dimension: "Human beings, enriched by civilization and modernism could not escape the exposure to a culture of fear, especially in the last century. Despite all measures of those in power; terrorism, harassment, theft, the spread of infectious diseases, AIDS and the loss of hygiene, especially in developed countries of the West, cause their people to live with constant anxiety." (Furedi, 2001).

Susan Sontag, in her book Disease as Metaphor, tells how some sectors enslave and exploit societies by benefiting the fear that diseases such as cancer and AIDS create in humans and creating a new sector. (Sontag, 2005: 67). When we analyze the root of syphilis disease, the causes of this disease are related to the unpreventable sex drives of humanity. Today, rape and sexual violence, which are encountered almost everywhere in the world and published in the media, have something to do with this disease. It is observed that those who have not been unable to control their sex drive since the first period of humanity tend to rape. The increase in these rape incidents brought with the requirement of taking precautions in Europe. The measure was also the idea of opening a brothel where single and young men could meet their sexual needs for a certain fee. This idea would later become widespread in many countries around the world: "Public officials, who were all elderly and married men, thought that the best way to protect their wives and end rapes was to open a brothel. Some of these houses were small, four-room huts; others could have twenty rooms or even could cover a large building, and this was the case especially in cities where there were many priests. Brothels, where married men were not assumed to go, offered single men cheap, good sexual intercourse with a licensed prostitute. (...) Public baths were also rich places in terms of sexual pleasures... Naked men and women used to laugh and joke in outdoor pools which are accessible to people of all classes." (Nikiforuk, 2013: 130)

The fact that sexual intercourse got an increasingly anomalous nature brings with an increase in diseases. Increased same-sex relationships and tendency for 
zooerasty brought sexual disorders with it. When these disorders increase a lot, some people begin to discredit the other sex, thus ending the period of having sexual intercourse with every Tom, Dick, and Harry. In some places, when prostitutes use this disease as a way to take revenge on society, they are exposed to violence: "Sexual intercourse has lost its naturalness after syphilis. Men began to discredit women, and women began to discredit men. D.H.Lawrence, who's thought more about sexuality than experiencing it, suggests that the 'absolute hidden horror' of the disease has an 'immeasurable large impact' on British, Spanish, and American thought. Fear was never great enough to stop the spread of the disease, but it was very real. (...) The horror of syphilis most affected the image of men and led to prostitutes being treated cruelly. Although it was homeless men who carried and spread the disease, homeless or working women became the carrier of the disease." (Nikiforuk, 2013: 137)

Syphilis disease, which is an indicator of extramarital relationship and brings social exclusion, has also inspired artistic works in terms of causing bodily deformations: "The change in the sources of disease that the artist encountered in the historical process revealed the similarities of the form. The syphilis epidemic causing body deformation as in the case of leprosy has been a disease where leprosy-like social alienation is intense and sick people are excluded. For artists, these deformations in the human body have become art forms that strengthen the form." (Yabalak, 2020: 532-533).

Adrian Leverkühn, who contracts syphilis in the novel, hides his disease from everyone. For an artist with an idealistic spirit, this can be evaluated as his effort to hide his servile emotions as this is also the way he is known around. So we are faced with a character who refuses to be treated and to tell the truth to the doctors who come: "Adrian doesn't want a doctor; Because he wanted to think that his misery was something he actually knew and that his migraine attacks which he inherited from his father escalated acutely. It was Frau Schweigestill who brought in Dr. Kürbis. This kind-hearted man didn't dwell much on migraines; because these extreme headaches were not unilateral as seen in migraine cases. Looking at the emergence of pain on both eyes as if they were carved, they should have been rather considered as a side effect of another disorder."(Mann, 2014: 499).

Adrian suffers greatly from syphilis to which he has been contracted. His friend describes these sufferings as follows: "Leverkühn, to which I conveyed these impressions, was in a lot of pain at the time - suffering from a disease that manifested in the form of humiliating distortions almost done with hot pliers and not directly life-threatening but that making someone hit the bottom: So much so that he could hardly make it from one day to another. It was nausea that appeared with very severe headaches that could not be stopped even with 
the strictest diets; it lasted for days, repeating within a few days; he was vomiting for hours or even days with his empty stomach." (Mann, 2014: 498). Adrian Leverkühn talks about his disease in his autobiography: "I, the painful creature, had gone aside and rested in bed with great headaches all day long, and I had heaved and vomited several times as in severe cases." (Mann, 2014: 327).

Inspired by the devil during this period when he suffered health problems, the artist quickly made wooden carvings called "Apocalypse cum Figuris", which was the spirit of the time, and composed a great work called "Apocalipsis cum Figuris" (Apocalypse in Paintings) inspired by Dante's cantos of hell. Apocalypse was performed in 1926. According to the narrator, despair prevails in the work: "It portrays a lot from Dante's poetry. But most of all, it is the musical picture where the bodies come out of it, and the angels play the drums of the setting... Where the dead are resuscitated and the saints pray... in short, a crowd with groups and scenes about the apocalypse." (Mann, 2014: 522). In the novel, Mann describes Apocalypse as a metaphor for the dangerous modernist bourgeois, arm-in-arm with fascism.

A genius artist, Adrian Leverkühn, creates great compositions in line with his agreement with the devil. The compositions he created attract a lot of attention. The pieces he plays at his concerts are like the summary of his life and tell of his downfall: "The Faust cantata is separated from Revelation, above all, by great orchestral transitions. (...) It's the opposite of the Ode to Joy. Exactly the negative of the enthusiasm of the vocals in the $9^{\text {th }}$ symphony; It's almost like retaking it back. My poor great friend! I thought who knows maybe how many times he predicted and projected many more collapses in this work, and I remembered the painful words he said to me at the time of his child's death. This shouldn't have happened, there shouldn't have been goodness and joy; it must be taken back, it must be taken back! Oh, it shouldn't have." (Mann, 2014: 709).

Thomas Mann, as in all his works, builds this work, which can be considered a masterpiece, on the axis of an intellectual character. The work is the product of an intensive effort in which various disciplines are used together. Psychology, philosophy, religious science, and music are the branches that feed the work. The thoughts of many philosophers are processed in this work. The author receives technical support from many artists, especially musicians. He can also be described as a postmodernist writer in terms of referring to intertextuality: "Another trend of postmodernism is the current application of 'intertextuality', which seems to fall under the influence of visual technology in the way of period-based way of life. The postmodernist writers of the early years, who liked to use the references from the world of books in their texts, 
are now influenced by the images created by cinema with great technological possibilities leaving aside all Hamlet/Faust/Don Quixote. "I think it is important to know the 'Lord of the Rings', 'Star Wars' and 'The Matrix' to understand the popular culture of the last decade. These films are the parts of today's mythology," says author Mehmet Aç. "I'm more influenced by cinema than literature. (...) Those who love David Lynch movies can also love my books," says one young writer. We can say that the definitions of 'inter-art relations' or 'interdisciplinarity' replace intertextuality in the period-based way of life, where electronic visualization gain favor rather than text/written art." (Ecevit, 2013: 28-29). Although he belongs to a bourgeois family, he criticizes the bourgeoisie and Nazi fascism. His work Death in Venice has been criticized by many for praising homosexuality. In the following period, this anarchist pays the price of his personality by being denationalized.

In almost all of Thomas Mann's works, it is seen that the problem of the artist is treated and the autobiography and fiction are intertwined. As reflected in his work, Goethe is an artist whom he inspires as style and content. He expresses his admiration as follows: "I always admired, I always consider my ability to admire to be the most necessary thing to become something myself, and I don't know where I would be without him." (Reich-Ranicki, 1991: $200 \quad 73)$.

Through his characters, he treats his own perception of art and worldview in his novels. These are the author's own opinions, albeit sometimes contrary to social understanding. In this novel, the artist also treats both the aesthetic and moral breakdown. His successful treating of universal subjects with a narrative technique and his orientation to various disciplines, especially medicine, brings him the Nobel Prize. In many of his works, the spiritual supremacy of surrendering to aesthetics becomes a catastrophe driven by passion and leads to the collapse of moral values. He aims to get away from or even get rid of the decadence atmosphere that marked the literature at the turn of its century with neoclassicism. (Mann, 2013: 6).

Mann, who takes the reader on a journey to a world where there are artistic and philosophical discussions on the axis of intellectual characters in almost all his works, informs the reader in the finest details of the music in this work. Gürsel Aytaç also expresses his inability to get rid of the Goethe influence despite his ability to hide the autobiography arising from his mastery in this style: "The observation, the flow of thought and the search for serenity are felt in almost every scene although the style partially conceals that the author was inspired by his observations. It is understood that this moderate style comes from the Goethe school, and Mann's is close to Goethe both in terms of a humanistic and artistic sense." (Aytaç, 2010) 
Thomas Mann's works are suitable for references to each other. In "Death in Venice", which was adapted for cinema in a period: “(...) the ship that brought the main character Gustav von Aschenbach to Venice is called Esmeralda. That name appears as a character in Mann's Dr. Faustus story, as well. As we can understand in the next scenes of the film, Esmeralda is also a prostitute with whom Aschenbach has one night stand (this relationship fails). In short, Esmeralda serves as a means of facing the real self by being staged in Venice and represents also a person who has become a means to make him understand his true sexual identity. We can assume that Visconti, who cares about memories and cultural heritage and is passionate about literature, must have read Thomas Mann's words that "in order to inherit the heritage, one must understand it." (Geitel vb. 2006:53) In both works, "Esmeralda" is a means that leads the main character to death.

The main character of this novel, Adrian Leverkühn, is not successful at all in his relationship with women. It can be said that the sensitive structure resulting from the artist's persona affects this failure. Ines's attitudes with whom he considered getting married for a while annoys him: "He should have said that Ines was using him and his body, in fact, just like a man uses a woman in a correctly established relationship -unhealthy and coercive jealousy was added to this - and with a completely improper and unjustified sense of ownership. He was saying, "improper and unjustified", and he was tired of her and her pressure..." (Mann, 2014: 511).

One of the reasons why the author called this work "Faustus" may be to reveal one's desire to know, as well. For some reason, human beings tend to become a god by dominating nature with the abilities they want to have: "The character of Faustus is a symbol of the dominance that man tries to establish on nature. The desire to dominate this nature, which we conceptualize as a culture, is the most important element that pushes the Faustus character into tragedy. While Faustus wants to know, he actually wants to replace God. He aims to establish an absolute hegemony over nature and he chooses the path of cooperating with Satan, i.e. with humane ambitions to achieve this power.

Today, the triumph of scientific knowledge has helped us gain superiority over nature. However, our efforts towards obtaining information also have negative impacts on this victory. We can say that breakthroughs in science, and urbanization - industrialization are responsible for global warming, cancer, the risk of nuclear war, and unprecedented aggressive behaviors in history. Faustus is actually a prototype of man who wants to know, but on the other hand, harms nature." ( Retrived from: http://www.mimesis-dergi.org/2015/01/bir-kucuktanri-faustus/). 
In this work, which he wrote as a work of his master stage, the author does not abstain from making political criticisms while describing how a proud artist fell upside down with the syphilis epidemic: "Thomas Mann, in his latest work, Doctor Faustus, walks us around the tense world of a proud artist, composer Adrian Leverkühn. Even though his spirit is filled with a desire to create, the tension of Leverkühn, who is unable to keep down his irrational and anti-sentimental temperament, is the greatest obstacle to his power to create. Satan addresses Leverkühn at this weak point: By making the artist contract a venereal disease, Satan makes the artist pay the price for getting out of an existence doomed to remain meaningless without the manifestation of the creative mind. But this is a genius and creativity that only evil can provide, and it represents the intoxication of people with fascism in Thomas Mann's aesthetics. Interpreted by Mann as the surrender of the developed community spirit to archaic primitiveness in the human body, this chronic political issue, which makes the threat felt in the social field today as much as it did yesterday, appears on the individual basis that creates a gap between aesthetic spirit and bourgeois life in the novel." (https://www.neokur.com/kitap/139837/doktor-faustus)

One of the reasons why Thomas Mann's work is characterized as a masterpiece can be evaluated as the adaption of the carnival and grotesque that began with modernism to the novel. In this highly voluminous work, the good with the bad as well as the fun with the piteous and the negative are told together. "In the twentieth century, grotesque was strongly revived, but the phrase "revival" doesn't quite fit into many new forms. In general terms, there are two main development lines in this period. One of them is the modernist line (Alfred Jerry). This line is associated with romantic tradition at various levels and has evolved under the influence of existentialism. The second line is realistically grotesque (Thomas Mann, Bertold Brecht, Pablo Neruda, and others). This line is associated with a tradition of realism and folk culture, and sometimes it reflects the direct impact of carnival forms." (Bahtin, 2005: 74).

In the novel, Dr. Serenus Zeitblom's orientation as the narrator, and Leverkühn's orientation as the artist to internal conversations from time to time can also be considered as the construction of the work by the psycho-narrative method: "Since the study of a time range always points to the presence of a narrator who has a distant and general view of events, the brief psycho-narration is rarely seen in character novels. But although the traditional mind analysis has disappeared, the psycho-narration itself has in no way disappeared from the modern worldly literary scene. One reason it exists alongside the modern monologue technique is its time-wise flexibility: Because it can narrow the long time frame, or it can expand the moment. Besides, as Nathalie Sarraute points out, the expanded moment - 'now expanded in an outrageous 
way'- is the favorite time-space for modern novelists. In reality, psycho-narration is rarely used only to follow the stages through which consciousness passes, since it can do so only in the form of plain indirect narratives - 'he understood that', 'he asked himself...' - and that can be easily monotonous. Indirect thought quotes are in most cases quickly replaced by more direct monologue techniques. This method is preferred only by writers who like to interfere with the thoughts of their characters with long comments: Jane Austen, George Eliot, Thomas Mann. In this psycho-narration genre, the prize must undoubtedly go to Proust, as he benefits greatly in the third-person narrative of $A n$ amour de Swann." (Dorrit, 2008: 50-51).

Dr. Serenus Zeitblom witnesses the downfall of his friend himself. He describes the last condition of Adrian Leverkühn, whom he saw for the last time in his life, as follows: "In 1939, I saw him once again. After the invasion of Poland, a year before his death, which is witnessed by his eighty-year-old mother, his mother took me up the stairs to his room, saying in encouraging words, "Come, don't hesitate, he won't notice you." (...) At the back of the room, once called Adrian Leverkühn, whose immortal side is still called by that name, was laying on a lounge chair; his feet were facing me under a woolen, light blanket, and his face was in a position where I could see." (Mann, 2014: 738)

This is the part where the author shakes the reader about the transience of life. How the proud and successful artist of a period became an inanimate object is told. (Page:437) The occurrence of various disasters in Europe in 1914 is also treated in the novel. The author describes the negativities of Nazi Germany by turning to political criticism when describing an artist's illness with his intellectual accumulation:" (...) No matter how impossible it was to easily associate the deterioration of his health with the catastrophe in the homeland, I felt to draw an analogy, an objective relationship between them. Due to his insurmountable distance to external matters, I kept myself this conclusion which I had come to as they are simultaneous, and I avoided speaking against him even in an implied manner." (Mann, 2014: 499).

The years 1929-1930 caused Germany to be ruined by blood and flames. Thomas Mann also makes references to the fate of the country from time to time when describing the life of Adrian Leverkühn. Leverkühn's plan, which he considered getting married during this period, does not come true and he loses his beloved nephew. Adrian Leverkühn, who violated the rule of staying away from love according to his previous agreement with the devil and broke the deal, is shaken by the death of his five-year-old nephew Nepomuk. As the artist was going through a depression, the devil made him write the composition "The Lamentation of Doctor Faustus" with new inspiration. Leverkühn, 
who later composed other works, begins to collapse physically and spiritually due to the Syphilis disease he caught.

On August 25, 1940, the great artist Adrian Leverkühn succumbed to the Syphilis disease he once caught, and died in great pain. There was no one but a few friends at his graveside: "On August 25, 1940, in Freising, I received the news that the remains of his life, which had brought me a very important meaning full of love, curiosity, fear, and pride, came to an end. In Oberweiler's small cemetery, before his open grave, besides his relatives, there was Jeanette Scheurl, Rüdiger Schildknapp, Kunigunde Rosenstiel, and Meta Nackedey, and an unrecognizable, covered foreign woman. She disappeared as the first soil fell on the coffin.”(Mann, 2014: 739).

The author, in fact, tells the story of the collapse of Germany through his persona. In 1940, Adrian Leverkühn is buried in a modest ceremony attended by several of his friends. The author deals with individual pain in connection with social crises with the responsibility of an artist who witnesses his age. This sensitivity also aims to raise reader awareness for the treatment of problematic thoughts: Thomas Mann says, "As one person, one lives not only his own life but also the lives of those of his era and contemporaries." Loyalty to a certain era shows an inclusive feature as a social indicator of evaluation. A very important thing in terms of motivation in the evaluation is the social formation in which the evaluating subject lives. At a certain age, different socialeconomic formations can exist side by side. Based on a particular social formation (pre-requiring a class society), the individual is in favor of a specific class or the position of a particular class and represents a particular class. There is no need to even discuss the role of the class trait that the motivation in the assessment carries. Just like there can be several main differentiation between the class and the intelligentsia, it is seen that some differentiation, which is important for the literature, appear within a class. Meanwhile, there are national and ethnic characteristics that can have an impact as a social indicator." (Redeker, 1986: 118).

The author suffers greatly in his own country while he criticizes politically. As an intellectual writer, he is punished by the Nazi regime for defending principles such as human rights and democracy, and is forced to leave his own country: "Thomas Mann, like many famous writers, worked actively against the Nazi regime and paid a heavy price for it. The Nobel Laureate, who was denationalized of his German citizenship in 1936, as known, had to emigrate first to Switzerland and then to the United States in 1938. What makes him universal is that the themes he treated in his works continue to pass from generation to generation without losing anything from their actuality. Although 
Thomas Mann himself said in the past that he would be credited with the Buddenbrooks, The Decline of a Family works such as The Magic Mountain, Death in Venice, and Doctor Faustus made him a truly universal writer. In Doctor Faustus, a novel of universal scale, while the famous author, who questions the Nazi regime and Nazi Germany, says that the war that continues with all its unruliness will end one way or another in the scope of composer Leverkühn's deeply shaken life history, he expresses how shaken and appalled he is by the terrible mood of the German nation which such a bad fate has brought with the following striking words: The fact that Germany would leave the war defeated was so engraved in our consciousness and our memories as a nation that we were not so afraid of anything else as we feared the terrible consequences it would have. However, one thing we feared much more than that was the possibility that Germany would prevail in the war. Some of us considered Germany's defeat as a murder, while others said that its victory would be much more terrible than its defeat." (Eğit, 2020: 1).

Thomas Mann criticizes with a patriotic identity, even when criticizing his country's negativities. In making this criticism, he also reminds us of the risk of high treason accusations in many countries, and emphasizes that his sole purpose is making his country a more habitable and libertarian country: "Stating that his mental state is slightly different from that of the German people who share the same fate, the author says that although he know that other nations have had to seek the defeat of their own state for the sake of their own future and the future of an entire humanity, and could not wish for such a terrible tragedy, a great catastrophe that had never happened before, for his own country, and continues: "Given the characteristics such as honesty, loyalty to the state and its values, obedience and a sense of trust unique to the German nation, I must also accept that this dilemma has turned into a double-edged knife in our case, putting us in an unprecedentedly very dangerous situation, I can't help but feel deep anger towards those who put such a good-natured nation in such a difficult position that no other nation would fall and alienate him to himself in an impossible way." Then he expresses the terrible state of mind that the German nation has fallen into with these appalling words: The fact that all my writings have fallen into the hands of my sons by an unfortunate coincidence, and my thought that they will have to report me directly to the secret police without any distinction with some kind of pride of nationalism, is enough to explain the profound dimension of the disaster we face and the dilemma we have been through." (Ĕ̈it, 2020: 1).

The narrator/author wants God to have mercy on the souls of his friend and homeland, linking the death of his friend Adrian Leverkühn to the great military, economic and sociological shock during world wars in Germany, where 
he was born, lived, and loved so much: "Germany was staggering with its flustered cheeks at the height of its wild victories at that time; it was preparing to take over the world with the power he obtained from an agreement it signed with his blood, and to which it was determined to stick. Today, surrounded by demons, he closes one of his eyes with his hand, and the other stares at brutality rolling from desperation to desperation. When's he going to hit the bottom? When will the miracle that will bring the light of hope that appears at the endpoint of despair be born according to belief? Clasping his hands, a lonely man prays: "Lord, have mercy on the poor souls of my friend and my homeland!" (Mann, 2014: 739).

Besides syphilis disease, the novel also mentions the typhus epidemic: The narrator who goes to war is sent home due to typhus: "Until the Battle of Argonne in 1915, I would only remain on the front lines for about a year, after which I would get typhus under some adverse circumstances, be shipped to my house with an iron cross." (Mann, 2014: 444).

In the study, the narrator himself catches typhus while his friend is infected with syphilis. This disease usually spreads due to inadequate hygiene conditions: "Typhus; it is a type of infectious disease that is transmitted from one person to person through lice and fleas. Some sources also call it typhoid fever and stained typhoid. This disease is spread through lice and fleas that carry the Rickettsia bacterium from one person to another. As seen when the narrator caught the epidemic in the military, typhus is a disease most commonly seen in crowded and unhealthy environments: "This disease is more common in places where living conditions can be poor, such as prisons and refugee camps. Typhus manifests itself with symptoms such as headaches, fever, and skin rash. It spreads more in winter and spring severely." (As Harden\& Kiple, 2008: 1080 from Yolun, 2012: 53)

The narrator says that his separation from his friend Adrian on his way to war hurt more than the typhus he was caught. So he mentions typhus once again: "I was going to the front on horseback, or I shouldn't go at all." $\mathrm{He}$ caressed the neck of an imaginary horse. We laughed. When I was going to the station, it was easy for us to say goodbye, it was cheerful. I'm glad it wasn't emotional; otherwise, it wouldn't have been appropriate. But I was taking Adrian's last look with me to the war - maybe it wasn't the typhus I contracted from lice apparently that would bring me back home in a short time, it was that look." (Mann, 2014: 452).

Typhus exhausted armies in wars and caused the destruction of a large number of soldiers, directly affecting the outcome of the war. A large number of refugees died from this disease in the mass migration: "In Granada in 1489, 17,000 soldiers died of typhus in the army of King Ferdinand of Spain. The 
number of soldiers killed in battle is only 4 thousand. (...) Refugees who crossed the Atlantic Ocean by ships played the biggest role in transporting typhus outbreaks from Europe to North America. A striking example; in 1847, 75,540 Irish people went to Canada as refugees. 30 thousand 265 of the refugees caught typhus, and a total of 20 thousand 305 refugees lost their lives, 5 thousand 293 of whom during the sea voyage, whereas 8 thousand 12 in Quebec and 7 thousand in Montreal. (As Encyclopedia Britannica, 1968: 446 from Özdemir, 2005: 39).

Today, it is thought to affect deaths in Coronavirus disease (Dağlar, 2004: 15'retrieved from 15 Yolun, 2012: 13) "Pneumonia" is one of the diseases mentioned in the novel. As the three friends chat during dinner, the narrator asks about Ursula. "Between the ins and outs of Clementine Schweigestill, I decided to ask Adrian about his sister Ursula in Langensalza. She was happily married, and in terms of health, she also recovered from mild pneumonia in the upper lobe of his lungs, which she was caught due to two births in a row in 1911 and 1912." (Mann, 2014: 445).

As a result, Thomas Mann makes his intellectual identity apparent in Doctor Thomas, which is described by some critics as a masterpiece as seen in his other novels. He acquires the habit of turning to almost all disciplines, especially art and medicine, in his novels. The reader also improves his/her overall culture as $\mathrm{s} / \mathrm{he}$ goes back and forth in the storyline. In this context, the author does not neglect to inform his readers. In this novel, the details of music science add value to the novel even though it benefits from the others. The bad consequences of syphilis are treated over an artist. How this disease knocked out Adrian Leverkühn, who composed great compositions, step by step and led him to a tragic death as a result of his agreement with the devil was addressed in the novel. The author also associated syphilis with Germany's political, economic, and democratic deterioration due to Nazi rule. In addition to syphilis, typhus and pneumonia were also mentioned in the novel.

\section{Teşekkür}

$\mathrm{Bu}$ çalı̧̧ma, Bitlis Eren Üniversitesi Bilimsel Araştırma Koordinatörlüğünde BEBAP 2021. 15 numaralı proje ile desteklenmiştir. Çalışmamızı maddi olarak destekleyen Bitlis Eren Üniversitesi Bilimsel Araştırma Projeleri Koordinatörlüğü’ne teşekkür ederiz.

\section{Thanks}

This study was supported by the project numbered BEBAP 2021. 15 under the Scientific Research Coordinatorship of Bitlis Eren University. We thank Bitlis Eren University Scientific Research Projects Coordinatorship for financial support of our study. 


\section{Prof. Dr. NURULLAH ULUTAS}

\section{REFERENCE}

Aytaç, Gürsel (2010). Thomas Mann'ın Edebiyat Dünyası. Ankara: Phoenix Yayınevi Bahtin, Mihail (2005). "Rabelais ve Dünyası”, çev. Çiçek Öztek, İstanbul: Ayrıntı Yayınları. Cohn, Dorrit (2008). Şeffaf Zihinler (Kurmaca Eserlerde Bilincin Sunumu), İstanbul: Metis Eleştiri Yayınları.

Dağlar, Oya (2004) "War, Epidemics and Medicine in the Ottoman Empire from the Balkan Wars through the Great War" Unpublished Phd. Thesis, Istanbul: Boğaziçi University Institute of Social Sciences.

Ecevit, Yıldız (2013). "Seksen Sonrasından Günümüze Edebiyat”, Kurmaca Bir Dünyadan, İstanbul: İletişim Yayınları.

Encyclopedia Britannica, (Chicago, William Benton Pub., 1968), Vol. 22, s. 446.

Furedi, Frank. (2001). Korku Kültürü (Risk Almamanın Riskleri). (Translator: Barıș Yıld1rım). İstanbul: Ayrıntı Publishhome

Genelkurmay Baskanlığı, (2011). Birinci Dünya Savası'nda Doğu Cephesi'nde Sağllk Hizmetleri, Ankara, Genelkurmay Basımevi,

Harden, Victoria A. (2008). "Typhus Epidemic", The Cambridge World History of Human Disease, Ed. Kenneth F. Kiple, Cambridge University Press, Cambridge.

https://www.insanokur.org/faust-johann-wolfgang-von-goethe-insan-kendini-yalnizca-insanda-tanir/(Erișim Tarihi: 20/10/2021)

http://www.mimesis-dergi.org/2015/01/bir-kucuk-tanri-faustus/(Erişim Tarihi: 20/10/2021) https://www.haber7.com/kitap/haber/1110392-doktor-faustus-ilk-kez-turkcede (Erişim Tarihi: 08/10/2020)

https://www.neokur.com/kitap/139837/doktor-faustus (Erişim Tarihi: 20/10/2021)

Eğit, Kasım "Venedik'te Ölüm - Thomas Mann, "Sanatçının trajik çıkmazı?" https://www.insanokur.org/venedikte-olum-thomas-mann/ (Erişim Tarihi: 08/10/2020).

Mann, Thomas (2013). Venedik’te Ölüm. (Önsöz) (Çev. Behçet Necatigil), İstanbul: Can Yayınları

Mann, Thomas (2014). Doktor Faustus. (Çeviri: Zehra Kurttekin), İstanbul: Can Yayınları

Nikiforuk, Andrew (2013). Mahșerin Dördüncü Atlısı (Salgın ve Bulaşıcı Hastalıklar Tarihi), (Çeviren Selahattin Erkanl1), 5. Bask1, İstanbul: İletişim Yayınları.

Özdemir, Hikmet (2005). Salgın Hastalıklardan Ölümler (1914-1918), Ankara: Türk Tarih Kurumu Basimevi.

Redeker, Horst (1986). Edebiyat Estetiği, (çev: Aziz Çalışlar), Ankara: Kuzey Yayınları.

Reich-Ranicki, Marcel (1991): Thomas Mann und die Seinen, Fischer, Frankfurt.

Sağlam, Tülin (2010). "Siyah Pelerinli Adam'da Faust", Ankara Üniversitesi Tiyatro Araştırmalart Dergisi, S. 29, s. 8, DOI: 10.1501/TAD 0000000236

Schreiber, W. (1987). Infectio, Infectious, Diseases in the History, (Schwitzerland, Roche Ed., 1987), s. 143.

Sontag, Susan (2005). Metafor Olarak Hastalık (Aids ve Metaforları), (Çeviren Osman Akınhay), İstanbul: Agora Kitaplığı.

Türkeş, Ömer (2013). "Doktor Faustus, Thomas Mann", http://dipnotkitap.net/ROMAN/Doktor_Faustus.htm (Erişim Tarihi: 20/10/2021)

Ulutaş, Nurullah (2016). “Arketipsel Eleștiri Bağlamında Turgay Nar'ın Gizler Çarşısı Oyunu Üzerine Bir İnceleme / An Investigation on Turgay Nar's Play Titled Gizler Çarşısı within the Scope of Archetypal Criticism", TURKISH STUDIES -International Periodical for the Languages, Literature and History of Turkish or Turkic-, ISSN: 1308-2140,Volume 11/10Spring2016, ANKARA/TURKEY, www.turkishstudies.net, DOI Number: http://dx.doi.org/10.7827/TurkishStudies.9688, p. 659-680. 
AKRA KÜLTÜR SANAT VE EDEBIYYT DERGİSI 2022 (S.26) c.10 / s.193-209

Yabalak, H. (2020). "Sanatçının Esin Kaynağı Olarak Salgın Hastalık ve Hastalığın Resim Sanatına Yansıması". Van Yüzüncü Yıl Üniversitesi Sosyal Bilimler Enstitüsü Dergisi, Salgın Hastalıklar Özel Sayısı.

Yolun, Murat. (2012). Íspanyol Gribinin Dünya ve Osmanl Devleti Üzerindeki Etkileri. Adıyaman: Adıyaman Üniversitesi, Sosyal Bilimler Enstitüsü, Tarih Anabilim Dalı, Yayınlanmamış Yüksek Lisans Tezi. 